\title{
Impact of polyethylene glycol on porosity and microstructure of sand-lime product
}

\author{
Paulina Kostrzewa ${ }^{1, a}$ and Ryszard Dachowski \\ ${ }^{1}$ MSc, Kielce University of Technology, 25-315 Kielce, Poland \\ ${ }^{2}$ Dr Eng. Prof. PŚk, Kielce University of Technology, 25-315 Kielce, Poland
}

\begin{abstract}
Autoclaved sand-lime products are environment-friendly building materials in the form of bricks and blocks. Due to great interest in silicate products, there have been numerous studies and modifications aimed at improving the properties of the material. The article presents the most important characteristics of sand-lime products, both traditional as well as modified with polyethylene glycol. The purpose of described research was to estimate porosity (determine the type, size and pores distribution) and to analyze the microstructure of aforementioned samples. From the practical point of view, these characteristics are particularly important in the construction materials. The following tests have been carried out: bulk density using the hydrostatic method, capillarity, water absorption and mercury porosimetry of samples containing polyethylene glycol. The samples were also subjected to observation of the microstructure under the scanning electron microscope. Preliminary research findings clearly show the positive influence of the used substrate on the basic properties of modified sand-lime product. In comparison to the reference sample, modified products showed a decrease in water absorption and reduced capillarity. The confrontation of the measurements made using a mercury porosimeter with observation of the microstructure, showed differences in the distribution of pores and their size. Besides the additive, the production process itself has a huge impact on the properties of silicates (mixing process, time and temperature of autoclaving).
\end{abstract}

\section{Introduction}

Autoclaved sand-lime products (silicates) are manufactured from natural raw materials, so they are classified as healthy and ecological materials [1]. Silicates, which are characterized by high compressive strength and durability, are an excellent acoustic and thermal insulator. In addition, they are completely non-flammable, resistant to frost and growth of microorganisms $[2,3]$.

Silica brick is becoming increasingly important as a construction material. It is willingly used for the construction of load-bearing walls, partitions, curtain walls and foundation. Sand-lime blocks are characterized by dimensional accuracy and allow to reduce the risk of improper leveling of each layer $[4,5]$. Low water absorption of silicates allows the erection of silicates cladding walls. Most of masonry elements must be quickly plastered, while walls made of sand-lime blocks can be safely left without plaster. They will not be damaged under the influence of atmospheric factors. Polish Standard PN-EN 19962:2010 [6] says that silicates can be used in wet and humid conditions. Silica brick does not emit unpleasant odor, even when saturated in water and its bright color provides a friendly interior of the basement.

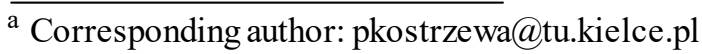

The aim of the work is modification of the composition of traditional sand-lime products, which will result in better porosity of the material, which as a consequence will be more resistant to water penetration. The authors wish to maximize these properties of silicate bricks, which are important in terms of the usefulness of this material for making foundation and cladding walls.

The composition of traditional sand-lime products was modified by introducing the additive in the form of polyethylene glycol. Selection of the additive was based on its interesting properties, such as: polyethylene glycol penetrates into the wood structure displacing water; it is resistant to solutions of acids, alkalies and salts, non-toxic and colorless [7]. Polyethylene glycol is used in the pharmaceutical and cosmetic industries as well as in the textile industry, leather industry and wood industry [8].

\section{Methodology of research}

In order to carry out laboratory tests of modified sandlime products, cuboidal samples were prepared with dimensions of 40x40x160 mm. The samples were prepared in the Silicate Production Plant in Ludynia (Poland). 
The sand was mixed with quick lime and water in appropriate proportions. Then the mixture was placed in a reactor, where the process of lime slaking took place.

The next step was the addition of the substrate in a percentage presented in the Table 1. After mixing all the ingredients, the mass was placed in a trigeminal steel mold and pressed under a pressure of $20 \mathrm{MPa}$. Then the mass was placed in an autoclave for 8 hours at a temperature of $203^{\circ} \mathrm{C}$ and a pressure of $1.6 \mathrm{MPa}$. Removed from the molds, the samples were stored for 21 days under required conditions of temperature and humidity.

Table 1. Composition of the samples.

\begin{tabular}{|c|c|c|}
\hline $\begin{array}{c}\text { Sample } \\
\text { symbol }\end{array}$ & $\begin{array}{c}\text { Sand-lime mass } \\
{[\mathbf{\%}]}\end{array}$ & $\begin{array}{c}\text { PEG 400 } \\
{[\mathbf{\%}]}\end{array}$ \\
\hline $\mathrm{N}$ & 100 & 0 \\
\hline P1 & 99 & 1 \\
\hline P2 & 98 & 2 \\
\hline P3 & 97 & 3 \\
\hline P4 & 96 & 4 \\
\hline P5 & 95 & 5 \\
\hline
\end{tabular}

"A" represents a traditional sample and "P1-P5" are modified samples (depending on the amount of the additive). The mass composed of: quick lime (about $7 \%$ by weight of the product), sand (about $90 \%$ ) and water (about 3\%). The used additive was polyethylene glycol (PEG 400) having a molecular weight of 400 Da..

\subsection{Density}

Specific density is a ratio of mass of dry sample to its pore volume. The study was conducted using a helium pycnometer on the reference sample and samples with polyethylene glycol (with the best strength parameters).

\subsection{Buk density}

Bulk density is a ratio of mass of dry sample to it's the sample to the apparent density (including pores). Because of the irregular shape of the sample, the test was performed using a hydrostatic method.

\subsection{Porosity}

Porosity determines what part of the volume of the material constitutes the pore volume. It is an important feature, on which characteristics such as strength, frost resistance, thermal and acoustic insulation depend [10].

\subsection{Mercury porosimetry}

In this method mercury is injected into the pores under pressure. Knowing the amount of mercury used in the test, the pore volume can be estimated [9]. Moreover, when the pressure rises, smaller pores are penetrating and thanks to that determining their size is possible [2]. IUPAC classification of pores due to their size: micropores $(\mathrm{dp}<2 \mathrm{~nm})$, mesopores $(2 \leq \mathrm{dp} \leq$ $50 \mathrm{~nm})$, macropores $(\mathrm{dp}>50 \mathrm{~nm})$. The minimum diameter that can be measured depends on the maximum pressure obtained during mercury pressing.

\subsection{Microstructure}

Samples of the sand-lime products were subjected to observation of their microstructure under the scanning electron microscope to determine the distribution and pore geometry.

\subsection{Capillarity test}

Capillarity is a phenomenon of transporting water upward through the element. The amount of capillary water increases with decreasing pore diameter [9]. Water absorption effects are visible in the form of moisture stains in the lower parts of walls. Capillarity depends on the porosity and pore size. To determine this characteristic of the material, properly prepared samples were placed in water to a depth of $5 \mathrm{~mm}$. When placed in water, samples were weighed and measured after 10,30 and 90 minutes according to the recommendations of the PN-EN 772-11: 2011 [11]. The level of moisture and weight increase of the sample were investigated.

\subsection{Absorbability}

Absorbability is the mass of water which can be absorbed by a sample, completely immersed in water, at atmospheric pressure. Typically, absorbability of building materials depends on the porosity. This is due to the fact that water cannot get into the closed pores, while in the case of large pores - it only moistens their walls [7].

\section{Results and discussion}

The study shows that the modified products have slightly lower specific density and bulk density. The volume of pores in the samples constitutes $33.5 \%$, and the tightness (both of the sample with the additive and traditional one) is $0.665 \%$. These studies enable to determine the total volume of the pores. However, they do not provide any information on their shape and size.

Table 2. The test results density and porosity.

\begin{tabular}{|c|c|c|}
\hline Sample symbol & $\mathrm{A}$ & $\mathrm{P} 1$ \\
\hline $\begin{array}{c}\text { Density } \\
{\left[\mathbf{g} / \mathbf{c m}^{\mathbf{3}}\right]}\end{array}$ & 2,595 & 2,585 \\
\hline $\begin{array}{c}\text { Bulk density } \\
{\left[\mathbf{g} / \mathbf{c m}^{3}\right]}\end{array}$ & 1,726 & 1,719 \\
\hline $\begin{array}{c}\text { Tightness } \\
{[\mathbf{\%}]}\end{array}$ & 0,665 & 0,665 \\
\hline $\begin{array}{c}\text { Porosity } \\
{[\mathbf{\%}]}\end{array}$ & 33,488 & 33,511 \\
\hline
\end{tabular}

The results of tightness, density and porosity tests are shown in Table 2. Sample "A" is a traditional sand-lime 
product, and $\mathrm{P} 1$ is a sample containing $1 \%$ of polyethylene glycol (characterized by improved compressive strength).In order to determine the pore size mercury porosimetry was used. Modified sand-lime products is characterized by lower content of mesopores than traditional product, which is about $15 \%$. The number of macropores in the sample P1 is about $85 \%$. Small number of pores with low diameter is beneficial, because the high of capillary rising is inversely proportional to the diameter of the capillary. It means that the modified material absorbs less water compared to the standard sample. Volume pore size distribution is shown in Figure 1.

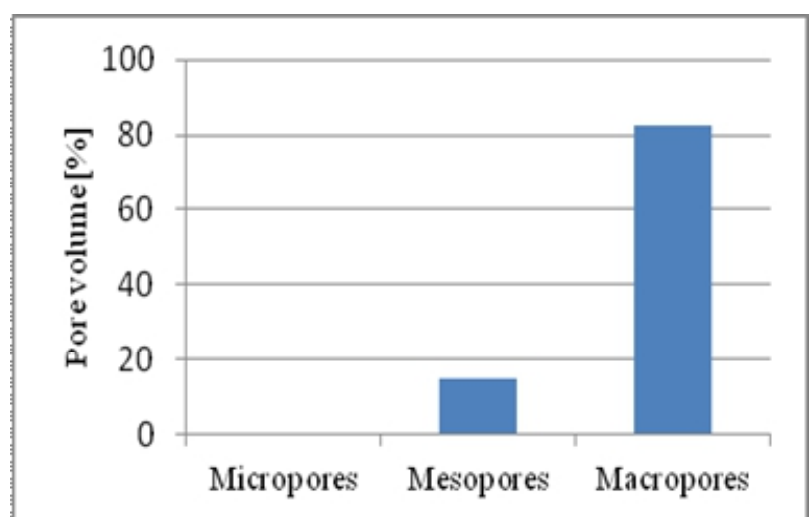

Figure 1. The pore size distribution in the modified product.

SEM observations allowed to point out differences in the distribution, shape and size of pores in tested materials. In a silicate with the addition of polyethylene glycol (Fig. 2) evenly distributed pores with a circular shape are present. Pores in size from 100 microns to 400 microns are visible. Traditional sample (Fig. 3) has smaller pores with an oblong and irregular shape, the size of which is from 50 microns to 350 microns. Microscopy with higher resolution would probably register pores with significantly smaller diameters. Moreover, a disadvantage of this method is a small representative of the sample which is analyzed.

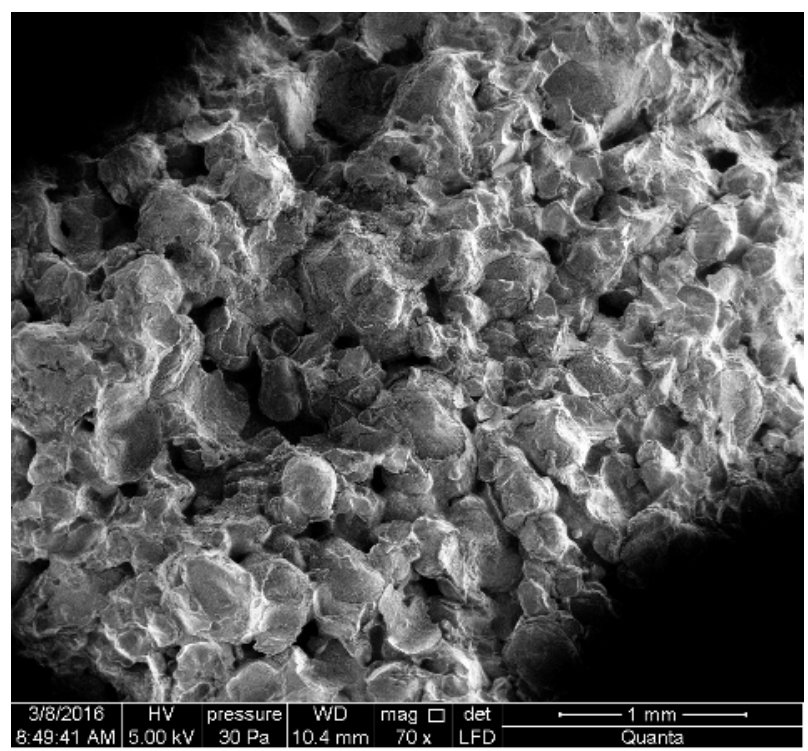

Figure 2. SEM picture of the modified sample.

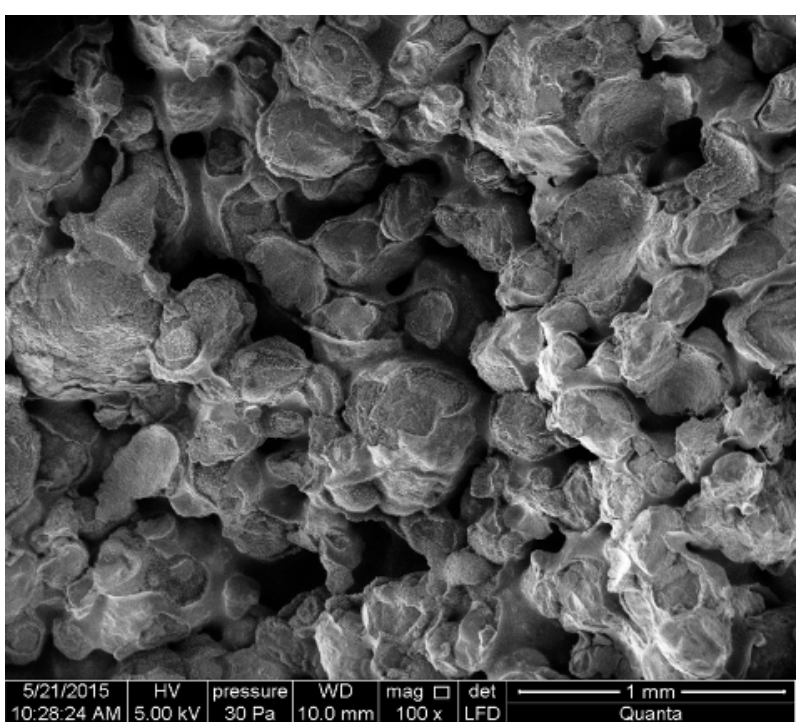

Figure 3. SEM picture of the traditional sample [12].

Behavior of the material exposed to moisture have been investigated using capillarity (Fig. 4) and absorbency measurements. The results of capillarity (Fig. 5) revealed a significantly lower capillary rising in the samples with the addition of polyethylene glycol. Modified samples absorbed about $60 \%$ water less than traditional product.

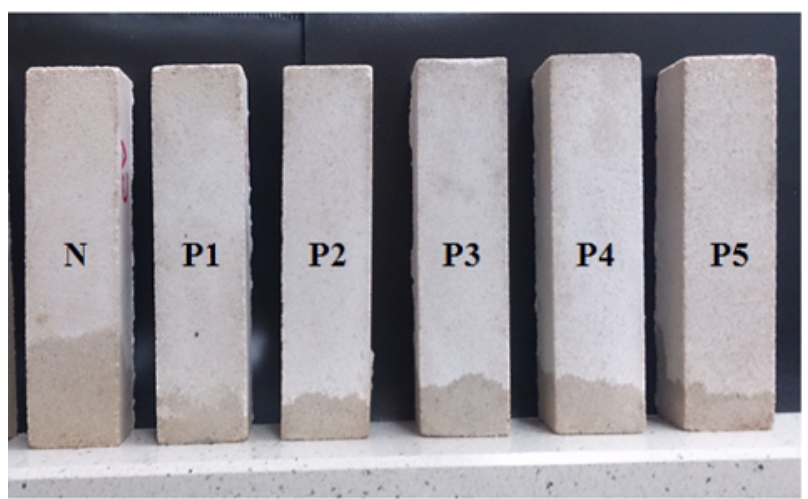

Figure 4. Examination of capillarity.

The use of a modifier in an amount of $1 \%$ or $5 \%$ gave a similar result in water adsorption test. With the increase of the substrate in the sample, the absorbency of samples slightly decreased.

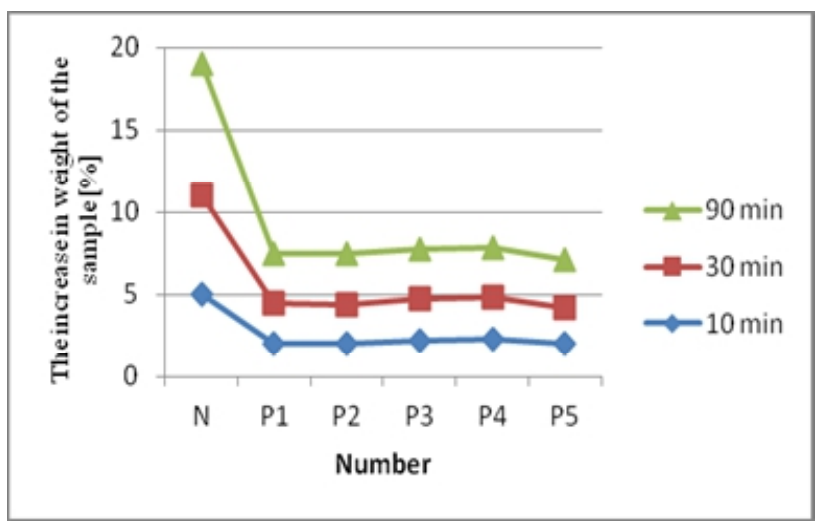

Figure 5. The results of the capillarity test.

Saturation of the material with water depends mainly on the type of the material and type of pores. The study 
of absorption showed that polyethylene glycol has a positive impact on this feature in the modified products. Decrease in water saturation from $6 \%$ to $3 \%$ was noted with $4 \%$ of polyethylene glycol in comparison to traditional silicate products (Fig. 6).

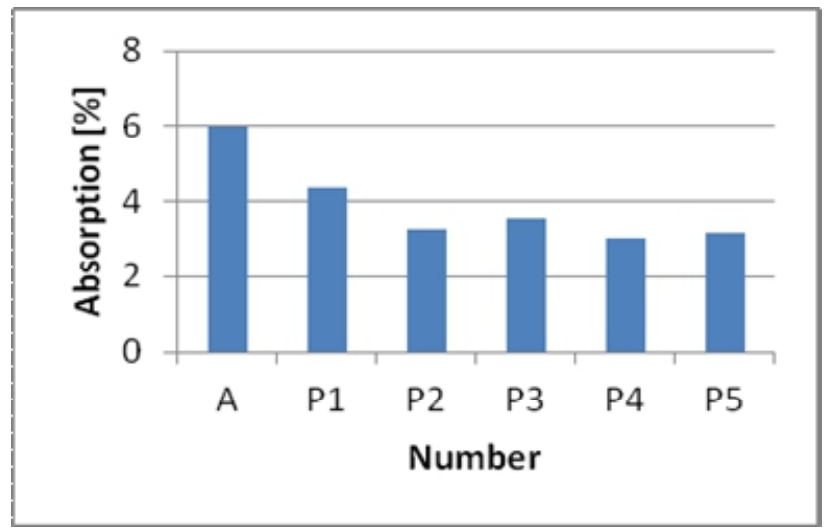

Figure 6. The results of the absorption test

\section{Conclusions}

1.The addition of polyethylene glycol has a beneficial effect on the properties of the resulting sand-lime products, what depends on the amount of the substrate. 2.Change in the composition of the silicates has improved physical features such as capillarity and water absorption.

3. Studies conducted by using mercury porosimeter showed that the modified silicate products are characterized by reduced number of mesopores and increased number of macropores in comparison to the traditional products.

4.Despite the small differences in the density and porosity of the traditional product and product with the additive, a significant reduction in capillarity and water absorption was observed. This is caused by changes in the pore structure.

\section{References}

1. S. Lewowicki, Zarys technologii materiałów budowlanych (2000)

2. L. Lichołai, A. Szalacha, Materiały budowlane $i$ ich badania laboratoryjne (2005)

3. A. Sieniawska-Kuras, Tradycyjne $i$ nowoczesne materiaty budowlane (2011)

4. M. Nowek, The 9th International Conference "Environmental engineering, pp 1-6 (2014)

5. R. Dachowski, A. Stepien, Procedia Engineering, 21, pp. 1173-1178 (2011)

6. PN-EN 1996-2:2010 - Projektowanie konstrukcji murowych -- Część 2: Wymagania projektowe, dobór materiałów i wykonanie murów

7. M. Dziewońska, Związki wielkocząsteczkowe polimery (1995)

8. J. Ciabach, Ochrona Zabytków 36/3-4 (142-143), pp. 223-226 (1983)

9. J. Małolepszy, Materiały budowlane. Podstawy technologii i metody badań (2008)
10. B. Stefańczyk i inni, Budownictwo Ogólne, 1 (2005)

11. PN-EN 772-11:2011 - Metody badań elementów murowych -- Część 11: Określenie absorpcji wody elementów murowych $\mathrm{z}$ betonu kruszywowego, kamienia sztucznego i kamienia naturalnego spowodowanej podciąganiem kapilarnym oraz początkowej absorpcji wody elementów murowych ceramicznych

12. A. Stępień, K. Komisarczyk, Ochrona przed Korozją 59, pp.49-51 (2016) 